\title{
Waste Disposal Problems and Management in Ughelli, Nigeria
}

\author{
Sunday I. Efe \\ Department of Geography and Regional Planning, Delta State University, Abraka, Nigeria. \\ Email: efesunday@yahoo.com
}

Received January $11^{\text {th }}, 2013$; revised February $13^{\text {th }}$, 2013; accepted March $12^{\text {th }}, 2013$

Copyright (c) 2013 Sunday I. Efe. This is an open access article distributed under the Creative Commons Attribution License, which permits unrestricted use, distribution, and reproduction in any medium, provided the original work is properly cited.

\begin{abstract}
The study examined the problem of waste disposal and management in Ughelli. A field survey was undertaken to determine the types, volume, effects and methods of managing solid waste in the Ughelli. The volume of waste was measured at dumpsites in the four existing quarters and from household bins. Appropriate waste characterization methods were employed in classifying the waste into various components on weekly basis. Eighty and twenty questionnaires were administered to households' heads and industries respectively and summarized with descriptive statistics. The results revealed an increase in the volume of solid waste generated over the years with 15,540 Kg mean annual volume of solid waste generated in Ughelli at dumpsites, and $1104.7 \mathrm{Kg}$ mean volume of solid waste generated per households that never arrives at dumpsites. The composition of solid waste generated and disposed in Ughelli were predominantly food items, bottles/cans and plastics, paper/carton and nylon of sachet water, which were mostly found in market places. The most widely adopted method of waste disposal is open dumping, land filling, dig and bury. It is therefore recommended that government should adopt an appropriate waste collection and disposal agency and also more government approved dumpsites should be established in the area.
\end{abstract}

Keywords: Waste; Disposal; Management; Ughelli

\section{Introduction}

[1] defined solid waste as non-liquid and non-gaseous products of human activities regarded as being useless and could take the form of refuse garbage and sludge. Waste generation and disposal is one environment problem that has been of great concern to local inhabitants, local, state and federal government, as well as the world in general [2], 2008; [3]. In Nigeria, an average resident encounter in his household, institution and industry some tones of solid waste every year. According to [4] a major consequence of rapid urbanization is the growing generation of waste, and many city authorities face unprecedented challenges in managing. However the word "Waste" is highly subjective, while some persons see waste as a risk to public health and the environment, some find it as a mere necessary inconvenience and nuisance-necessary because it must be generated as long as man exist in the world to carry out day-to-day activities. From his perception, waste is a source of income [5]. [6] noted that the disposal and management of solid waste in developing countries, has continued to pose serious chal- lenges due to the absence of an appropriate and organized waste disposal and management culture and technology which arises largely from financial constraints, and this is due to the fact that most towns in developing nations are almost choked up as a result of the process of urbanization, which is one of the major features of the 21st century. In Nigeria, available records show that in 1921 only $8 \%$ of Nigeria's population was living in urban areas, the figure rose to $20 \%$ in $1970,30 \%$ in 1993 , and $40 \%$ in 1996. One of the problems associated with the high concentration of populations is that of waste generation and thus, its disposal and management.

Nigerian cities generate solid waste at an alarming rate such that in most cases, the volume of waste generated is often more than what the city system could absorb or handle. The characteristics of their problems range from inadequate housing, lack of potable water leading to unsanitary neighborhoods. Therefore, the health impacts of the latter problem cannot be far fetched as the incidence of typhoid, malaria fever etc. attacks among urban residents can be attributed largely to the deterioration of their immediate environment. Furthermore, due to rapid urba- 
nization, the provision of infrastructural facilities is not enough to serve the growing population. In effect, most of the available services are often overstretched and this has posed a serious problem to urban inhabitants [7]. In fact the volume of waste, tend to grow with increasing population, production and consumption in Nigeria. Solid waste disposal and management have defiled various solutions mainly due to poor infrastructural facilities, coupled with low budgetary allocations to them $[2,8]$.

[7] have hinted the lack of adequate awareness on the part of the general public on the management of waste from domestic and commercial sources. [1,2] observed that even where there seemed to be an organized refuse collection, disposal is often at open sites without considerations for the environment. Presently, very few cities in Nigeria can boast of a functional waste disposal system. Also, according to [2,7] most industries dump their solid waste in heaps within their premises while most households along the road turn the gutters into dumpsites which in turn, harbor and breed insets like mosquitoes, flies, cockroaches and maggots thereby, constituting public health hazards. [9] asserted that the way refuse are dumped along the road, can result in the blockage of roads. This type of situation is seen in the various communities of Ughelli main town. With the main concentration of refuse heaps at the Iwhreko market bridge, Afiesere junction, St. Theresa Grammar school road in Ekiugbo, Uduraran street, Olori road all other major roads in the town [2]. The problem of solid waste disposal by roadside can also result in flooding [10]. The bridge by Uloho avenue junction in Isoko road, Ikprukpru Street and a stream in Adagaragba road are surrounded by both residential and commercial buildings, which experiences annual flooding during the wet season, as a result of the large quantity of refuse heaps blocking the main drainage channels [2].

In Ughelli, there has been rural-urban drift, which has speedily increased the population of the town and in turn, has led to increase in the rate of waste generation and thus, the subsequent problem of its disposal and efficient management. This drift is as result of influx of workers both in the public, oil and other sector of the economy. Take for example Shell Petroleum Development Company (SPDC), Nigeria National Petroleum corporation (NNPC), Ministries and Government bodies, Primary and Secondary Schools, Majority of the commercial banks such as, Oceanic, PHB, Zenith, UBA, First, Union, first Inland, amongst others and the sitting of SETRACO Nig. Ltd., a construction company in charge of the dualization of the Warri-Kiama and the Ughelli main town road. As a result of these socio-economic activities, there has been an influx of people from neighboring towns and even foreigners employed by these companies. In addition to these workers there are also a large number of traders en- gaged in the buying and selling of goods and services in the various markets, especially on market days. These have precipitated in addition to the demolition and construction debris, sachet water nylon, broken bottles, scraps from vehicles animal wastes, vegetable matter, yam and plantain peels, corncobs, pieces of paper, road side banners, posters, etc. in Ughelli and environs.

These wastes can be found in heaps in the area as seen at Uduaran Street in Iwhreko community where there is a very large and illegal dumpsite situated on both side of the road. Also, in Emaearvwhore Street, there is a dumpsite very close to a nearby stream. Olori Street in Otovwodo community also experiences over flow of refuse helps along the road. The lukewarm attitude of the people towards environmental sanitation is very poor. The roads and streets are littered here and there with solid wastes. The major cause of poor environmental sanitation in the area, relates to poor administrative management and the lack of inappropriate technology to recycle wastes. These inabilities make the rapid generation and disposal of waste in the area serious problem, and the questions that agitate our minds is that what are the nature, type, method and volume of waste generated in the area? Based on the aforementioned problems and questions therefore, this study is set to examine the problem of solid waste generation and disposal in Ughell, Delta Nigeria.

\section{Study Area}

Ughelli is one of the major urban area in Delta state, which is located between latitude $50^{\circ} 28^{\prime} \mathrm{N}$ and latitude $50^{\circ} 32^{\prime} \mathrm{N}$ of the equator Longitude $50^{\circ} 58^{\prime} \mathrm{E}$ and Longitude $60^{\circ} 03^{\prime} \mathrm{E}$ of the Greenwich meridian, and Ughelli is a lowlying region of 0 - 100 meters above sea level with hyromorphic and organic soils as the major types of soils found in the area. The soil ranges from brown to sandy loam. As a result, both types of soil tend to develop a surface accumulation of peaty materials (10). The area is drained by river Ase a distributary's river of the River Niger. Also the area is riddled with an intricate system of natural water channels and valleys, culminating in poorly drained landscape [11]. Ughelli urban has a population of 82,994 [12] the town was originally an agricultural settlement but, rapid industrialization has taken place as seen in the presence of major oil and construction companies such as SHELL, NNPC, SETRACO, etc. There are also a host of other commercial organizations in the town ranging from banks, medical centers, educational centers, hotels religious organizations, etc. The major form of public transportation is the motorcycle, popularly known as Okada. In recent times, there has been a great migration from other part of the Niger Delta and Nigeria in general, making the town a "melting pot" comprising 
of all major tribes in the country including foreigners who come for investment and expatriate purposes as seen in the presence of the oil and construction companies, and consequently contributed to the volume of waste generated in the area.

Trading is of one the major activities of the people in the area, ranging from petty trading to large-scale outlets. This can visibly be seen in the various markets in the town such as main market, Ekiugbo market, Afiesere market, meat market and other surrounding markets, which plays host to a large number of traders coming from the towns and its environs. This has encouraged the indiscriminate disposal of waste along these areas.

\section{Methods of Data Collection}

The study adopted field survey research design of direct field measurement and administration of questionnaires. Field observation was carried out by conducting a preliminary field survey of the area under study; observing refuse dumpsites along the major roads and street, household refuse bins and the various methods adopted for their disposal (see Figure 1). During the observation, the various materials composed of the wastes were sorted and characterized into different classes, noting the predominant items and types of solid waste materials discarded by users in the area.

Also, the number of times collection vehicles and individual empting their wastes was also noted.

Direct field measurements were carried out with the aid of scales, pans, buckets, drums, hand gloves, and measuring tape from 1980-2010 with the aid of scavengers in each of the quarters where the dumpsites are

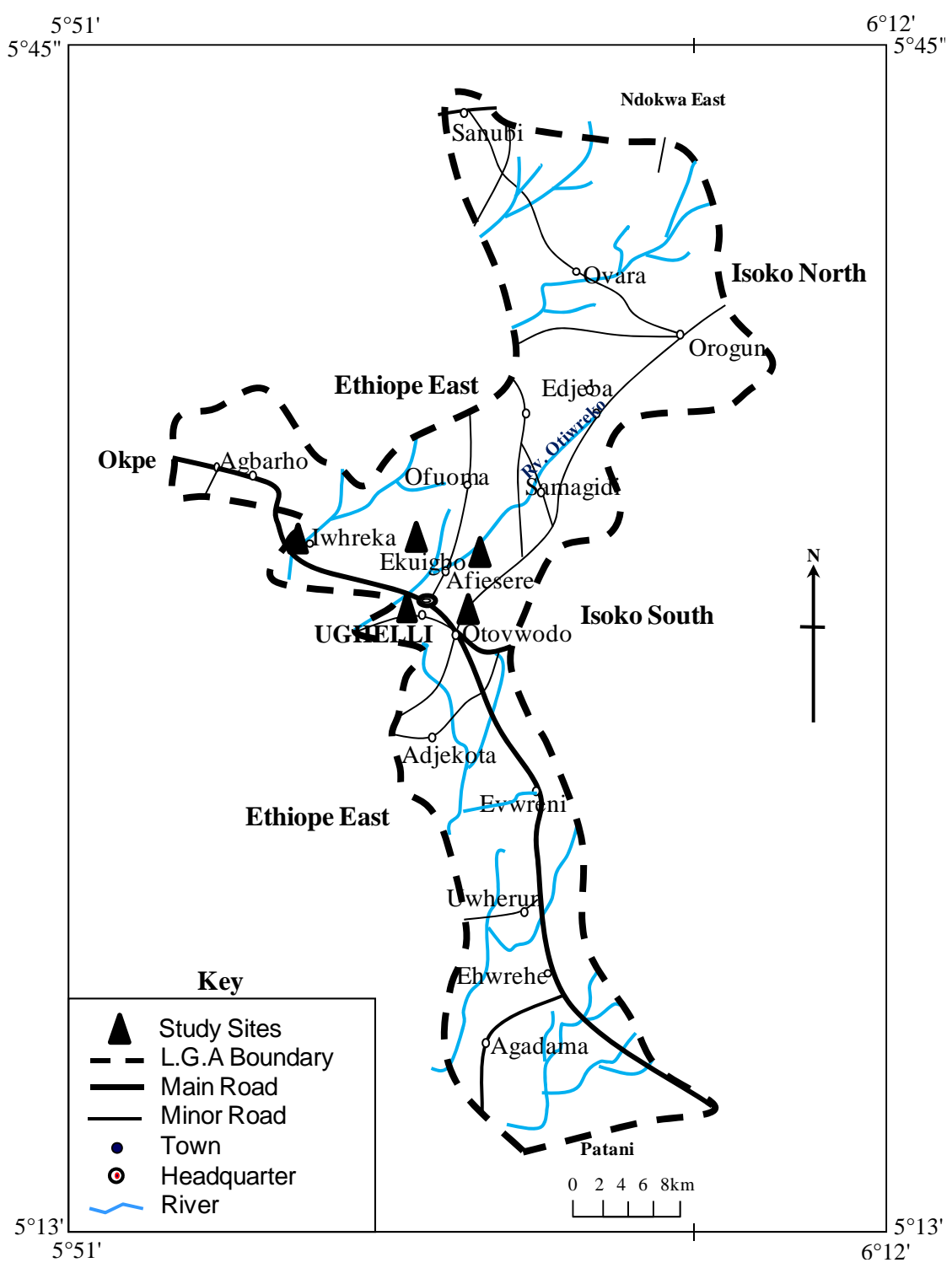

Figure 1. Map of ughelli north local government area showing the study sites. 
located on monthly basis. While the household wastes were measured with the aid of field assistants who resides within that neighbourhood, and they does the measurement of the households waste at the end of every week. Quadrant analysis was used to determine the volume of the wastes in the dumpsites. Four major and prominent dumpsites were selected from the four zones in the area. With the aid of the research assistants (scavengers), the length, breadth and height of each dumpsite was determined to get the area covered by wastes. To determine the volume of waste in the dumpsites, it was divided into portions with smaller area cover. That is one portion was measured to determine the area using the length, breadth and height. The portion was then emptied into buckets and placed on the scale to determine the weight $(\mathrm{Kg})$ after the procedure of weighing; a portion of the dumpsite's area using I by I $\mathrm{m}^{2}$ of the total volume of the dumpsite was determined using a mathematical equation: Area of dumpsite $=\mathrm{L} \times \mathrm{B} \times \mathrm{H}$, where $\mathrm{L}=$ Length of waste dump, $\mathrm{B}=$ Width waste dump, and $\mathrm{H}=$ Height of waste dump. The method has been adopted by [2] with a significant level of success. The result obtained was multiplied by the area of the dump site in each zone, and were average for every five years period.

Waste bins were kept at each household for domestic waste collection and measurement. The household wastes were measured on weekly basis by the research assistants in each household and sample analysis was carried out on them to determine the composition and volume (Kg). In doing so, twenty households were selected from the existing zone based on systematic sampling procedure of selecting a household at interval of 5 houses, which then amounted to 20 households in each of the existing four quarters. Thus 80 households were selected and used for the study. Waste disposal buckets were distributed to each of the selected houses. The household wastes collected were sorted and labeled: There was also characterization of the wastes to determine their composition. Weighing of the household waste was done on weekly basis, from which conclusions were made on the average waste generated per week and year.

On the other hand a total of 100 questionnaires were administered on the basis of eighty questionnaires to heads of the households selected and twenty to other sector (industries, schools, markets etc.). This was done to determine the sources of waste, frequency/methods of waste disposal, those responsible for the collection of household wastes, and the effect of waste in the area. Solid waste data were also extracted from the Federal Ministry of Housing and Environment for some Nigerian towns; this was done to aid comparison of waste generated in Ughelli with other urban areas in Nigeria. The data were summarized and discussed using descriptive statistics (mean, percentages).

\section{Results and Discussions}

During the recognizance survey to the dumpsites it was observed that scavengers visits the dumpsites to pick plastics, metals and inorganic material leaving the organic material made up of food remains, plantain, yam, potato, cassava peels, corncobs and other perishables which are the major cause of the stench and pollution emitted from these dumpsite. It was also observed that the dump sites were not legally sited as they were sited on the sides of major roads and streets, alongside residential and commercial buildings, which is very hazardous to man's health.

\subsection{Volume of Solid Waste Generated}

Table 1 shows the estimated and projected volumes of solid waste generated in some Nigeria cities from 1980 to 2010 and it indicate that the volume of solid waste generation in Nigeria has increased over the years. For instance solid waste in Ughelli ranges from $9243 \mathrm{Kg}$ in 1980 to $21,653 \mathrm{Kg}$ in August 2010, indicating an increase of $12,410 \mathrm{Kg}$ for the past twenty five years. However Lagos $(944,825 \mathrm{Kg})$ and New Busa $(8331 \mathrm{Kg})$ had the highest and lowest rate of increased. Same could be said of the other cities (see Table 1).

Table 1. Estimated volumes of solid waste generation $(\mathrm{kg})$ in some Nigerian cities.

\begin{tabular}{ccccccc}
\hline Urban Areas & 1980 & 1985 & 1990 & 2000 & ${ }^{*} 2005$ & ${ }^{*} 2010$ \\
\hline Lagos & 625,399 & 681,394 & 786,079 & 998,081 & $1,008,645$ & $1,570,215$ \\
Ibadan & 350,823 & 282,224 & 440,956 & 559,882 & 714,890 & 998,894 \\
Kano & 319,935 & 348,580 & 402,135 & 535,186 & 630,210 & 823,563 \\
Kaduna & 257,639 & 280,925 & 324,084 & 431,314 & 529,311 & 767,568 \\
Onitsha & 242,240 & 263,929 & 304,477 & 386,593 & 412,009 & 601,532 \\
Port-Harcourt & 210,934 & 229,821 & 265,129 & 283,853 & 467,346 & 633,458 \\
Osogbo & 131,903 & 143,712 & 173,720 & 253,841 & 335,623 & 451,768 \\
Aba & 131,903 & 143,952 & 169,719 & 236,703 & 301,326 & 433,946 \\
Jos & 99,871 & 111,905 & 135,272 & 197,660 & 278,353 & 416,750 \\
Warri & 67,477 & 75,607 & 91,396 & 133,531 & 232,395 & 401,654 \\
Gussau & 44,488 & 48,471 & 57,243 & 79,835 & 89,023 & 94,500 \\
Potiskum & 15,434 & 10,816 & 19,399 & 28,347 & 39,856 & 45,629 \\
Uyo & 12,508 & 13,628 & 15,721 & 20,923 & 26,348 & 43,126 \\
Suleja & 9383 & 10,514 & 13,311 & 21,336 & 25,721 & 32,234 \\
${ }^{* *}$ Ughelli & 9243 & 11,675 & 14,889 & 17,021 & 18,514 & 21,653 \\
New Busa & 5690 & 6200 & 7153 & 9518 & 11,764 & 14,021 \\
\hline
\end{tabular}

Source: Federal Ministry of Housing and Environment, the state of the environment in Nigeria, Monograph series, No. 2. Lagos. "Projected, ${ }^{* *}$ Fieldwork. 
Table 2 revealed that the mean annual volume of solid waste generated at dumpsites in the four zones of Ughelli was $15,540 \mathrm{Kg}$. Iwhreko has the highest mean annual volume with $5837 \mathrm{~kg}$ (see Figure 2 and Table 2), followed by Afiesere, with $3831.86 \mathrm{~kg}$. Otovwodo generated 3, $667 \mathrm{~kg}$ in their major dumpsite and Ekiugbo has the least mean volume in its major dumpsite with $2204.14 \mathrm{~kg}$. The high volume of solid waste from Iwhreko is as a result of the presence of the Ughelli main market in this area. This has earlier be noted in urban areas of Nigeria [see 1-5] who had earlier observed similar waste volume in Ughelli.

It is worthy of note that these dumpsites are a representative of all other dumpsites in Ughelli, however most of the waste were collected and disposed by individual and private agency and not by government agency. Thus most of the wastes generated never arrive at these dumpsites. It should be noted that these observed volume of waste in Table 2 from dumpsites in Ughelli corroborated those of $[4,7,13]$ in other urban areas of Nigeria, and that of $[2,5]$ who had earlier observed similar waste volume in Ughelli.

Table 3 showed the mean household waste generated in the four quarter of Ughelli to be $873.9 \mathrm{Kg}$ per households/year. Results revealed that Iwhreko also have the

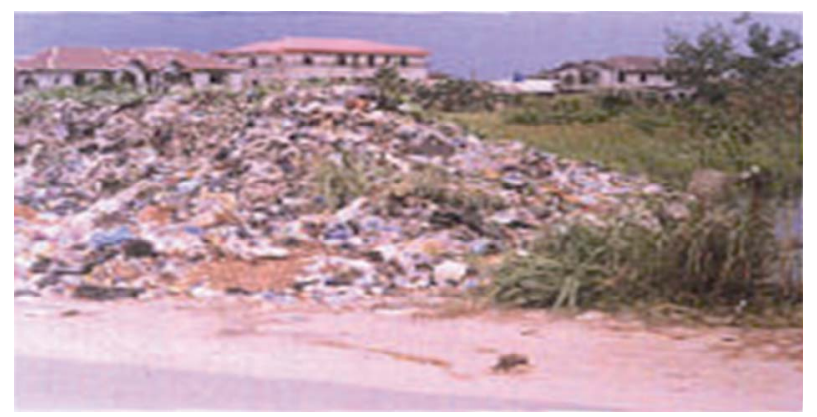

Figure 2. Waste dump at Iwhreko.

Table 2. Mean volume of solid wastes $(\mathrm{Kg})$ generated in dumpsites in the four zones of Ughelli.

\begin{tabular}{cccccc}
\hline Years & Afiesere & Ekiugbo & Iwhreko & Otovwodo & Total \\
\hline 1980 & 2011 & 1814 & 3415 & 2003 & 9243 \\
1985 & 3000 & 1901 & 4076 & 2698 & 11,675 \\
1990 & 3770 & 2068 & 5301 & 3750 & 14,889 \\
1995 & 4013 & 2107 & 5656 & 4009 & 15,785 \\
2000 & 4343 & 2148 & 6387 & 4143 & 17,021 \\
2005 & 4624 & 2175 & 7392 & 4323 & 18,514 \\
2010 & 5062 & 3216 & 8632 & 4743 & 21,653 \\
Mean & 3831.86 & 2204.14 & 5837 & 3667 & 15,540 \\
\hline
\end{tabular}

Source: Fieldwork. highest mean volume of solid waste generated in the area, with $232.6 \mathrm{~kg}$ and is closely followed by Afiesere 229.7 Kg, Ekiugbo (224.3 kg), and Otovwodo had the least volume of waste (187.3) kg. It can thus, be deduced that Iwhreko produces the highest volume of solid waste, as a result of the presence of the Ughelli main market. The sorting and characterization of the wastes into various classes showed that the waste generated generally composed of food wastes such as vegetables, peelings from yam, plantain, potato, cassava, corn, fish and meat waste and other food items. It also includes paper, carton, sachet waste nylon, Bottles, cans, plastic, glass and cloth materials from posters, banners, etc., baskets and other types of solid waste not mentioned (see Table 3 ). Table 3 also revealed that food remains are the highest with $314.2 \mathrm{~kg}$ which is followed by other types of wastes with $276.2 \mathrm{~kg}$, and next to this, is bottles, cans and plastic which accounted for $257.6 \mathrm{~kg}$. The least volume of household waste $25.9 \mathrm{~kg}$ was however recorded from paper, carton and satchel water nylon during this period. Hence the households in these area throwaway food items than any other type of solid waste.

Table 4 showed perceived household size and mean daily waste generated by them. From Table 4, 41\% of the respondents reside in homes with a population between 5 and 10, while $37 \%$ of the respondents have a household size, of less than 5 and 10 people. The implication here is that, $63 \%$ of houses in the area have an average of 5 - 10 and above with $7.10 \mathrm{~kg} /$ day mean perceived volume of waste, Table 4 also revealed that as the

Table 3. Mean composition of household solid waste (kg) generated in the four quarters.

\begin{tabular}{cccccc}
\hline Zones & $\begin{array}{c}\text { Bottles, } \\
\text { cans plastic }\end{array}$ & $\begin{array}{c}\text { Paper, carton, } \\
\text { sachet water }\end{array}$ & $\begin{array}{c}\text { Food } \\
\text { remains }\end{array}$ & Other & Total \\
\hline Afiesere & 65 & 9.4 & 88.4 & 66.9 & 229.7 \\
Ekiugbo & 61.6 & 6.2 & 78.6 & 77.9 & 224.3 \\
Iwhreko & 69 & 8.6 & 80.7 & 74.3 & 232.6 \\
Otovwodo & 62 & 1.7 & 66.5 & 57.1 & 187.3 \\
Total & 257.6 & 25.9 & 314.2 & 276.2 & 873.9 \\
\hline
\end{tabular}

Source: Fieldwork.

Table 4. Household size and mean daily volume waste (Kg) by respondents.

\begin{tabular}{cccccccc}
\hline Household size & A & B & C & D & Total & $\%$ & Waste/day \\
\hline Less than 5 & 9 & 8 & 10 & 10 & 37 & 37 & 3.21 \\
$5-10$ & 10 & 12 & 10 & 9 & 41 & 41 & 7.10 \\
Above 10 & 6 & 5 & 5 & 6 & 22 & 22 & 15.83 \\
Total & 25 & 25 & 25 & 25 & 100 & 100 & \\
\hline
\end{tabular}

Source: Fieldwork. 
size of household increases the volume of waste generated per household increases.

Solid waste disposal and management methods.

Tables 5-11 showed solid waste data obtained from the questionnaire responses.

Table 5. Perceived sources of solid wastes.

\begin{tabular}{lcc}
\hline Sources & Total & $\%$ \\
\hline Households & 27 & 27 \\
Market wastes & 42 & 42 \\
Industrial wastes & 13 & 13 \\
Establishment wastes & 10 & 10 \\
Agricultural wastes & 8 & 8 \\
Total & 100 & 100 \\
\hline
\end{tabular}

Source: Fieldwork.

Table 6. Frequency of solid wastes disposal.

\begin{tabular}{ccc}
\hline Frequency & Total & $\%$ \\
\hline Daily & 84 & 84 \\
Once a week & 6 & 6 \\
Twice a month & 7 & 7 \\
Monthly & 3 & 3 \\
Total & 100 & 100 \\
\hline
\end{tabular}

Sources: Fieldwork.

Table 7. Those responsible for the collection of household wastes.

\begin{tabular}{lcc}
\hline Responses & Total & $\%$ \\
\hline Government agency/NDDC & 12 & 12 \\
Private agency & 23 & 23 \\
Individuals & 65 & 65 \\
Total & 100 & 100 \\
\hline
\end{tabular}

Source: Fieldwork.

Table 8. Methods of solid waste disposal.

\begin{tabular}{lll}
\hline Methods & Total & $\%$ \\
\hline Open dumping & 54 & 54 \\
Land filling & 15 & 15 \\
Incineration & 7 & 7 \\
Dig and bury & 13 & 13 \\
Recycling & 7 & 7 \\
Composting & 4 & 4 \\
Total & 100 & 100 \\
\hline
\end{tabular}

Source: Field work.
Table 9. Availability of authorized dumpsites in the neighbourhoods.

\begin{tabular}{ccc}
\hline Response & Total & $\%$ \\
\hline Yes & 19 & 19 \\
No & 81 & 81 \\
Total & 100 & 100 \\
\hline
\end{tabular}

Sources: Fieldwork.

Table 10. Perceived effects of solid waste.

\begin{tabular}{ccc}
\hline Effects & Total & $\%$ \\
\hline Environmental despoliation & 35 & 35 \\
Health hazards & 26 & 26 \\
Economic & 17 & 17 \\
Social & 22 & 22 \\
Total & 100 & 100 \\
\hline
\end{tabular}

Source: Fieldwork.

Table 11. Diseases associated with solid waste.

\begin{tabular}{ccc}
\hline Illness/Diseases & Total & $\%$ \\
\hline Malaria & 38 & 38 \\
Typhoid & 20 & 20 \\
Cholera & 7 & 7 \\
Dysentery & 12 & 12 \\
Respiratory diseases & 23 & 23 \\
Total & 100 & 100 \\
\hline
\end{tabular}

Source: Fieldwork.

Table 5 revealed that markets in the area are the major sources of solid waste in the area, accounting for $42 \%$. Household wastes accounts for $27 \%$, industrial wastes, $13 \%$ are wastes from establishments $10 \%$ and the least is agricultural wastes accounting for $8 \%$. These responses indicate that the markets in the various zones yield the highest volume of solid wastes in the area. This is as a result of the dumping of wastes by traders in the markets.

Table 6 shows that $84 \%$ of respondents disposed their solid waste daily, while $6 \%$ and $7 \%$ of respondents disposed their solid waste on a weekly and twice a month basis, and only $3 \%$ of the respondents disposed their solid waste on a monthly basis. It is evident that individuals and companies in Ughelli dispose their solid waste more on a daily basis. This can be attributed to the sources of their wastes, as most of these wastes are from the markets and as such they disposed these waste daily at the close of the day's activities.

\subsection{Methods of Solid Waste Disposal}

From Table 7 Government agencies (NDDC) accounted 
for $12 \%$ of the collection of solid wastes in the area, $23 \%$ from private agencies, while the remaining $65 \%$ which is a very large proportion of the population disposed their wastes themselves. The implication of this is that the local government council Ughelli does not put any agency in place for the evacuation of solid wastes except the waste van provided by Niger Delta Development Commission (NDDC) in recent times for the evacuation of waste, which is not very regular and effective. Thus wastes are dumped indiscriminately in the neighbourhoods.

It is evident from Table 8 that open dumping with $54 \%$ is the major method of disposing and managing solid waste in Ughelli. Land filling accounted for 15\%, Dig and bury $13 \%$, Incineration and recycling has $7 \%$ respectively and the least method adopted is the composting method. The implication of this is that most households dump their refuse on roads, streets, available open spaces, gutters, market areas and other illegal sites. This corroborated $[2,3,5]$ who have earlier achieved a significant explanation on domestic waste. This is a source of health hazards to the people living in this area. Traffic congestion and inaccessibility of roads also results from this act of dumping wastes any how. The land filling method is the next adopted method but, it shows a very low patronage as a result of the limited knowledge and low level of sanitary conditions. This therefore causes air pollution as a result of the stench emitting from such land fills. Incineration is also a convenient method for the people living in this area but, the problem with this method is the air, air pollution and its inability to treat inorganic items of solid wastes such as, bottle, glass, metals, etc. However scavengers can do away with the bottles, glasses etc.

Dig and bury method is also highly adopted in this area. According to the residents it is relatively cheap to carry out, all they need is to dig a hole behind their houses and throw their refuse there. The hole is then covered when it is filled up and another one is dug. The recycling method is not very common as it involves a higher level of technology which is not readily available as a result of ignorance on the advantages of re-using products and lack of finance. The least adopted method, composting is the aerobic degradation of organic matter of waster which is not properly done in the area as, solid wastes is hardly sorted. So, the biodegradable component is not available.

It is evident from Table 9 that $81 \%$ of the respondents have no authorized dumpsites in their neighbourhoods while, 19\% have dumpsites around them. This has resulted in the indiscriminate dumping of wastes by the residents, along major roads and streets, behind houses and even turning the drainage system into dumpsites, as such resulted in the blockage of drainage channels thus, caus- ing traffic congestions and pollution from the stench emitted from the illegal dumpsite. This situation also implies that the local government council has done little or nothing to aid the effective disposal of solid wastes thus, resulting in mismanagement of the environmental needs in the area. It is observed that in this area, people tend to think that these illegal dumpsites are the proposed sites for dumping waste. So, there should be awareness via the media to enlighten the people on the disadvantages of dumping waste along major roads and streets. In turn, government should create dumpsites and ensure that the people make use of the authorized dumpsites.

\subsection{Perceive Effects of Solid Waste}

The effects of solid wastes in the neighbourhoods were indicated by the respondents, as shown in Table 10. Table 10 showed the environmental despoliations, health, and socio-economic effects of solid waste in Ughelli. These despoliations can be attributed to the damage being caused to the ecosystem thus, accelerating the destruction of the environment, pollution of underground water due to percolation and also, causing smog/air pollution in places where it is being indiscriminately burnt openly. Thus resulting in health and social effects which accounted for $26 \%, 22 \%$ respectively, and this is seen to lowering of the aesthetic values of the area especially in terms of recreation and tourism. On visits to the area, visitors are first welcomed by the unsightly heaps of refuse at the various corners of the town. Also, when waste dumped at roadside spill to the road, it obstructs free flow of traffic. Also, the proximity of there wastes to shops, residents and food items in the markets can lead to contamination of these foods by germs which eventually lead to epidemics of greater proportions. The economic effects accounts for $17 \%$. There effects of solid waste disposal are detrimental to the economy and the socioeconomic development of the area. Dumping of solid waste in gutters and channels causes great flooding problem, causing a disruption of economic activities, which in turn has adverse effects on the economy of the area. For example, flooding destroys and lowers the yields from farms. Also, constant congestion and overflow of refuse on the roads leads to the inaccessibility of such roads thus, leading to less mobility of the people in the area.

Table 11 revealed that $38 \%$ of the respondents suffer from malaria fever attacks as a result of the mosquitoes that bread on the wastes and gutters occupied by such wastes thus catering for a large number of the respondents. The stench from the waste causes respiratory problems and this accounted for $23 \%$, while typhoid accounts for $20 \%$ which as a result of contamination of drinking water either on surface or underground by the improper disposal of solid wastes. Cholera and dysentery accounts 
for $7 \%$ and $12 \%$ respectively, which is as a result of contamination of food and water taken by the respondents, and this can be deduced from the sales of food items in places very close to dumpsites. This is a common phenomenon of the markets in the area.

\section{Conclusion}

The study revealed an increase in the volume of waste generated over the years with 15,540 Kg mean annual volume of solid waste generated in Ughelli at dumpsites, and 1104.7 Kg mean volume of solid waste generated per households never arrives at dumpsites. However the highest mean volume of households' solid waste was recorded in Iwhreko with $303.4 \mathrm{Kg} / \mathrm{per} / \mathrm{household} \mathrm{per} \mathrm{an-}$ num and $5837 \mathrm{~kg}$ from dumpsites, and the least mean volume of solid waste $227.3 \mathrm{Kg} / \mathrm{per} /$ household and was recorded at Otovwodo per annum. The composition of solid waste generated and disposed in the area were predominantly food items (vegetable matter, meat, fish, peelings, etc., bottles, cans and plastics, paper/carton/sachet water nylon, and other categories of solid waste. The composition of these wastes in volumes are, $314.2 \mathrm{~kg}$ from food remains, others with $276.2 \mathrm{~kg}, 257.6 \mathrm{~kg}$ from bottles/cans and plastics, and the least $25.9 \mathrm{~kg}$ was obtained from paper/carton/sachet water nylon. These waste apart from those from households, others comes predominantly from markets, industries, schools and other establishments. It was observed that these wastes are disposed indiscriminately in the various neighbourhoods, thus causing environmental despoliation, health hazards, economic and social menace in the area. This corroborated the works of [2-4] respectively.

The study also revealed that the most widely adopted method of waste disposal in the area is open dumping, land filling, dig and bury, recycling, incineration and composting as the least method. And there is no effective means of solid disposal agency establish by government. This problem was as a result of the continued increase in the population of the area and also due to the fact of inappropriate technology, amongst others. This agrees with the results of $[3-5,7]$. It is therefore imperative that the Ughelli North Local Government Council and the inhabitants of Ughelli should brace up to engaging in regular environment sanitation to clear off the waste to approved dump sites. Also a change of altitude by all and sundry is desirable, this change will not only come from legislation or policy statements, or from the promises of government officials, instead, it must come from incremental efforts, working from clearing the waste in the markets and communities, down to individual household wastes. For example, garbage trucks should be provided; there should be an organization of a community group that transports garbage to an intermediary point, or helping several young entrepreneurs open a company that sells scavenged materials. These are the realistic actions to take and in the long run, can lead to strong institutions, interwoven business and community interests and perhaps even to well designed, practical government regulation. The Local government council should live up to her responsibility of evacuating the solid waste on daily basis.

\section{REFERENCES}

[1] T. G. Leton and O. Omotosho, "Landfill Operations in the Niger-Delta Region of Nigeria,” Engineering Geology, Vol. 73, No. 1-2, 2004, pp. 171-177. doi:10.1016/j.enggeo.2003.12.006

[2] O. A. Ishoka, "Problems of Solid Waste Disposal and Management in Ughelli Delta State, Nigeria,” Unpublished B.Sc Dissertation in Geological \& Regional Planning, Delta State University, Abraka, 2008, pp. 1-51.

[3] J. O. Babayemi and K. T. Dauda, "Evaluation of Solid Waste Generation, Categories and Disposal Options in Developing Countries: A Case Study of Nigeria," Journal of Applied Science Environmental Manage, Vol. 13, No. 3, 2009, pp. 83-88.

[4] V. I. Ogu, "Private Sector Participation and Municipal Waste Management in Benin City,” Environment Urbanization, Vol. 12, No. 2, 2000, pp. 103-117. doi:10.1177/095624780001200209

[5] E. O. Karibo, "Waste Management and Job Creation in the Niger Delta," A Paper Presentation at the 2nd Annual Dare 2, Dream Youth Summit, Effurun, 30 August 2008.

[6] R. Makinde, "Making Nigerian Towns and Cities Livable in the 21st century," 2000.

[7] J. C. Agunwamba, "Solid Waste Management in Nigeria: Problems and Issues," Environmental Management, Vol. 22, No. 6, 1998, pp. 849-856. doi:10.1007/s002679900152

[8] S. Ojeka, "Tax Policy and the Growth of SMEs: Implication for the Nigerian Economy," Research Journal of Finance and Accounting, Vol. 2, No. 2, 2011, pp. 16-26.

[9] L. F. Awosika, G. T. French, R. J. Nicholls and C. E. Ibe, "The Impact of Sea Level Rise on the Coastline of Nigeria," Proceedings of IPCC Symposium on the Rising Challenges of the Sea, Magaritta, 1992, pp. 14-19.

[10] O. O. Areola, “Soil and Vegetal Resource,” In: J. S. Oguntoyinbo, O. O. Areola and M. Filani, Eds., A Geography of Nigeria Development, Education Books Nig Ltd., Heinemman, 1978.

[11] R. K. Udo, “A Comprehensive Geography of West Africa,” Educaction Books Ltd., Heinemman, 1978.

[12] Nigeria Population Census, 1991.

[13] Federal Ministry of Housing and Environment, "The State of the Environment in Nigeria," Monograph Series, No. 2, 2000, pp. 2-19. 